\title{
ACTIVITIES TO ANTICIPATE THE WEAKNESSES OF STUDENTS' READING MATERIALS FROM THE INTERNET
}

\author{
Maria Vincentia Eka Mulatsih \\ English Department of Sanata Dharma University
}

\begin{tabular}{|c|c|}
\hline$\overline{\text { ARTICLE INFO }}$ & ABSTRACT \\
\hline $\begin{array}{l}\text { Received: } 15-04-2020 \\
\text { Accepted: 03-10-2020 } \\
\text { Published:12-10-2020 } \\
\text { Volume: } 4 \\
\text { Issue: } 2 \\
\text { DOI: } \\
\text { https://doi.org/10.33019/lire.v3 } \\
\text { i2.74 } \\
\text { KEYWORDS }\end{array}$ & $\begin{array}{l}\text { The way of reading has shifted from printed into non-printed materials (reading } \\
\text { from the computer, tablet and, smartphone). This shift affects students' learning } \\
\text { and reading processes inside or outside the class. Previous studies have shown both } \\
\text { the negative and positive effects on reading from the screen. This article provides } \\
\text { not only some weaknesses of the most visited internet source that had been } \\
\text { explored by ELESP students in Prose \& Book report classes, but also additional } \\
\text { activities to overcome the weaknesses which previous studies have not been } \\
\text { discussed. An Extensive Reading procedure was applied in those classes during } \\
\text { even semester 2018. Students were free to choose their reading materials which } \\
\text { consisted of two short stories and four novels for Prose class, three simplified }\end{array}$ \\
\hline $\begin{array}{l}\text { Students' reading materials, } \\
\text { internet, weaknesses, activities }\end{array}$ & $\begin{array}{l}\text { sources. Knowing the weaknesses of the source is needed so the teachers or } \\
\text { lecturers can anticipate the problem that can be caused by reading those materials. } \\
\text { It was found that students' reading material from a certain internet source did not } \\
\text { have a good structure of English due to some causes. Further activities for students } \\
\text { who choose certain internet source needs to be done so that students realize the } \\
\text { weaknesses and try to overcome them. }\end{array}$ \\
\hline
\end{tabular}

\section{INTRODUCTION}

The shift of reading preference from the printed version to online version challenges some reading classes. Dewi (2018) also shows some challenges in studying English Literature in Indonesia. Ideally, reading materials which are taken from printed version or internet sources should accommodate students' enjoyment. Thus, the main concept of ER (Extensive Reading) is needed as it underlines the importance of enjoyment when students read the materials. Freedom to choose the reading materials for students is pivotal. The consideration of those three important aspects which are online version reading, English literary learning, and student's enjoyment may appear like a challenging matter. This article's purpose is to build the connection of those three aspects by discussing the implementation of ER, a certain most visited internet reading source, its weaknesses, and additional activities to overcome the weaknesses. In short, this article is beneficial for students and lecturers. Students who learn English literature may enjoy their reading materials including online ones without ignoring some weaknesses of those materials. Besides, lecturers may also have some proposed activities as the addition after the implementation of ER.

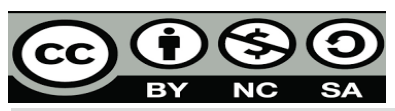

This work is licensed under Creative Commons Attribution-ShareAlike 4.0 Internasional. Copyright (C) 2020, Maria Vincentia Eka Mulatsih 
The ER concept that was applied is different from Nordin \& Eng (2016) idea that there should be a selecting reading materials based on genre (text type) and content (subject matter). Graded readers were absent. In some Prose \& Book report classes, the lecturer showed the list and gave freedom for students to choose their reading materials. The criteria for chosen reading materials were: 1) no movie version of the reading materials, 2) should be in English and 3) based on students' interest. The first criterion was decided to make sure that students would read the whole story. Story that had a movie version would make students watch the movie. For the second criterion, it dealt with all literary works across nations but they were written in English. The last criterion was the most important one due to the fact that students would enjoy reading the materials. The lecturer also told an additional instruction for students related to the difficulty of the reading materials. If students found five difficult words on a page, they might change their reading material. As students' need is more important in the learning process that teacher's belief or background (Wulandari, 2019).

Given that freedom, some students chose their own reading materials from the internet. On one hand, students said that it could make them read more. On the other hand, not all reading materials that were chosen from some internet sources were reliable. Thus, discussing the choice a reading material from internet matters. As a way, this article will provide information on the percentage of students' preference in choosing internet reading materials when ER procedure applied, the internet source that they liked for their reading and the weaknesses of that source. The weaknesses of the source need to be elaborated so that lecturer could anticipate what classroom action would be done to minimize its weaknesses. Finally, activities to minimize the weaknesses will be also proposed. Those activities are done so that students may have a 'mixed diet reading'.

\section{LITERATURE REVIEW}

In this digital era, reading from internet sources is unavoidable. Berardo (2006) states some facts as the rationale that reading from internet source is popular. The first deals with its accessibility and variety of the materials. The second is about the continuation of the updated version. The third relates to economical reason when internet source is compared to newspaper or other printed materials, the cost is cheaper. Not surprisingly in 2012 based on Picton's (2014) reports, young people from ages 8 to 16 read more on electronic devices and computers than in a printed version.

A 2012 Scholastic US survey of 1,000 US families found that the proportion of children who had read an ebook had almost doubled from 2010 (froms $25 \%$ to $46 \%$ ). "I'd read more books for fun if I had greater access to ebooks" (p. 7).

This online reading can lead to further activities. Allington \& Pihlaja (2016) show the shift from printed texts to e-texts together with the online interpretative practices. Not only the reading online materials, the discussion of the reading materials can also be done online. It shows that Internet affects reading. For the discussion, the readers can "share the quotation" (Rowberry, 2016) or "construct narrative or argument". In Indonesia, a research that was conducted by Son et al. (2011) reports that Indonesian teachers' computer literacy and typing skills level are adequate or higher. It is also stated that there must be an improvement in computer literacy after the past several years. Those are the facts that reading from internet sources becomes popular nowadays.

This work is licensed under Creative Commons Attribution-ShareAlike 4.0 Internasional. Copyright @ 2020, Maria Vincentia Eka Mulatsih 
The development of technology in form of internet can bring advantage and disadvantage for students, especially for their reading. Picton (2014) underlines that reading fiction whether it was through internet, magazines or books improved students' attainment.

Fiction reading has been associated with improved attainment, as noted in a 2012 Department for Education report: "Frequently reading novels and stories and reading for fun (regardless of whether this is through books, magazines or the internet) is strongly correlated to PIRLS literacy score" (p. 8).

Mulatsih (2018) also shows that reading fiction has a good impact. She connects students' chosen poems from internet with teaching practices. She underlines that poetry can be used as a medium for practicing teaching. The question whether the fiction reading materials can be the canon or not (Ndandara, 2017) does not matter. In addition, Picton shows the data that children tended to read fiction as e-readers $(75.1 \%)$, from smartphone (22.9\%), tablet (35.6\%), and computer $(30 \%)$ strengthened the point that reading from screen as a trend. Not only for the good of students' attainment, reading from screen especially eBooks can motivate students to read more:

At the same time, the number of children who felt that ebooks would have a positive effect on their motivation to read also increased significantly, with half (49\%) agreeing with the statement (Picton, 2014, p. 7)

In addition to Picton's reports, Coiro (2003) says that reading comprehension on internet is a kind of new literacy. He also compares the internet source and conventional one. The tendency of having internet source refers to internet as an interactive text.

However, there are some disadvantages of reading from screen based on some previous researches (Flood, 2014; Mangen, 2008; Strout, 2010; Wastlund et al., 2004). Wästlund, et al. (2005). They argue that reading from paper, students learn better. Mangen (2013) finds that the students who read on computers have less quality of performance than those who do it on paper. Strout (2010) investigates that students who are below average have the highest interest in e-books. Flood (2014) underlines especially for Kindle readers that they were not so good at recalling. Those who read paper were better than Kindle readers. Moreover, when we consider online reading materials, they cannot be read for those who are blind.

The tension of two sources of reading whether it is printed or on screen still cannot eliminate the essence of reading. The most important one relates to readers' enjoyment. Nuttal (1982) also agrees that enjoyment takes an important role during the process of reading. Once students enjoy the materials, they will continue reading other materials. In classes, when students have to read the materials that they do not like only for achieving good scores, it will be difficult for them to gain the enjoyment. Knowing the importance of students' enjoyment during reading process, one procedure that is called adaptation of Extensive Reading is applied. Based on the fact that the main purpose of ER is to gain readers' enjoyment related to their pleasure (Day \& Bamford, 2002).

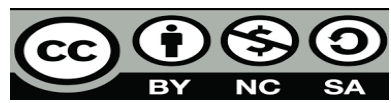

This work is licensed under Creative Commons Attribution-ShareAlike 4.0 Internasional. Copyright @ 2020, Maria Vincentia Eka Mulatsih 
Extensive Reading began to flourish in Indonesia and this procedure was proven to give benefits for learners in other countries (Ashraf \& Ahmad, 2003; Lien, 2017; Prowse, 2002; Yamashita, 2008). Basically, there were two points as background of applying the adaptation of ER procedure in some classes of ELESP. First, students had their own interest in reading certain themes. Second, each student had different ability to read based on his grade. For the first reason, when students chose their favorite genre, the level of enjoyment when students read a literary work would be better. Their reading process cannot be fun for them when there is an inappropriate list of reading materials from lecturer that they have to read. Reading, in this case, will be a compulsory activity.

The other reason deals with the different levels of students' ability of reading. Some students could not be categorized as intermediate learners. Previous research (Huh \& Ha, 2017) discusses that there are some students in college who choose children literature as their reading materials. It also happened with ELESP students who had different level of language acquisition.

\section{METHODOLOGY}

This section contains two parts, namely participants and data gathering techniques. Several steps have been done for completing this study. After the problem has been formulated, the writer asked for participants' agreement and gathered the data from the participants. The writer then classified the data and found the most visited internet reading source. Interview was conducted as the next step. It was continued with the process of data analysis. The last step was writing the result as the findings of this study.

\subsection{Participants}

There were 61 participants in this study which consisted of 29 students of book report class and 32 students of prose class. Students who were from book report class were in their first year of studying in ELESP while students who were from prose class were in their second year. Majority of participants from book report class were at low intermediate level and majority of participants from prose class were at intermediate level. For the first year students, they got some basic courses such as listening, writing, reading, speaking, pronunciation, vocabulary and basic grammar. In addition to that, students who were in their second year did not only get those basic courses but also some content courses such as introduction to literature, linguistics, and school management. They participated in this study for about four months during even semester $2017 / 2018$.

For book report course, students needed to read four novels that consisted of two simplified novels and two original novels. Students had to submit the report of the novels and there were three oral tests for the first until the third novels. Lecturer gave other option for students who wanted to read more. They might read three simplified novels and three original novels and make the summary of those novels. For Prose course, students needed to read two short stories and two novels. Some students chose to read two short stories and four novels.

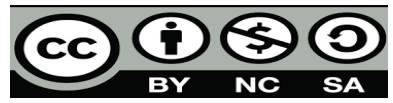

This work is licensed under Creative Commons Attribution-ShareAlike 4.0 Internasional. Copyright @ 2020, Maria Vincentia Eka Mulatsih 
The duration for both courses was the same including the number of the meetings. Both had fourteen meetings excluding the mid-term test and final test. Each meeting spent a hundred minutes. These courses were held in the even semester for 2017 - 2018 academic year.

\subsection{Data gathering techniques}

Some data would be shown in this paper. The first data were about the percentage of students' preference for choosing reading materials. Those data were taken from individual interviews after students finished their reading. The kind of interview that was done was closed one and it was conducted individually between the researcher and each participant. The interview was conducted in English. The second data that related to the internet sources were gathered together with the process of the first interview. When students answered that they read from internet sources, interviewer directly asked the internet source that they chose. Some stories which were taken from a specific internet source were based on the reading materials that students have read.

The third data about the weaknesses of a certain internet source were gathered from the text of a certain website and were analyzed by using document analysis (Bowen, 2009). A sample text as the third data was chosen based on its better quality compared to others. Besides, the regulation of the most visited website that became students' reading materials was analyzed too. In a nutshell, interview and document analysis were applied in this research. Mostly researcher used interview as the technique for data gathering.

\section{RESULTS AND DISCUSSION}

The charts below were the percentage of students' choice in relation with the sources of reading materials:

Figure 1. Reading materials in Prose Class Figure 2. Reading materials in Book Report Class
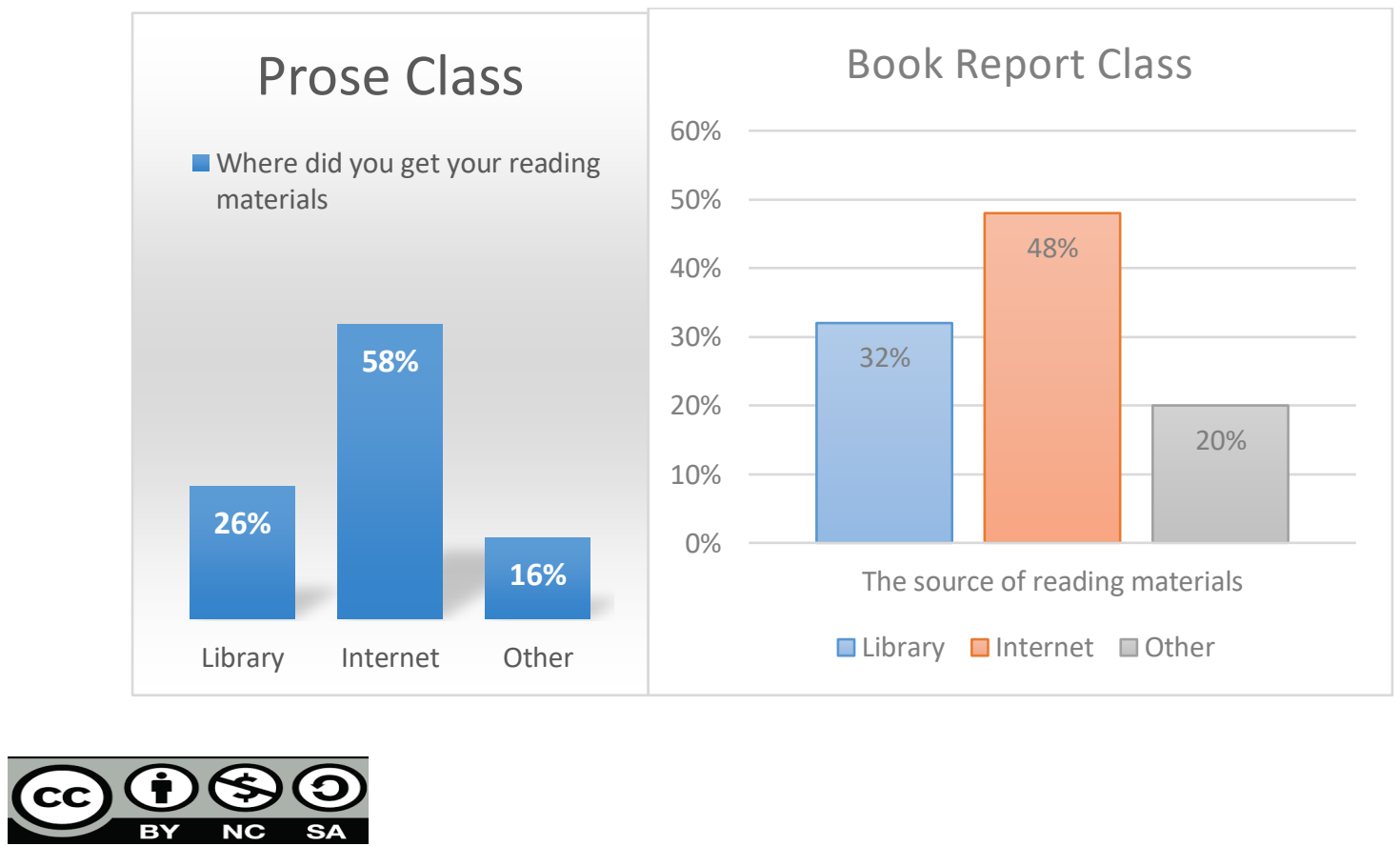

This work is licensed under Creative Commons Attribution-ShareAlike 4.0 Internasional. 
From two figures above, it was found that most students from prose and book report classes chose internet as their source of their reading materials. Reading materials from internet had the highest percentage based on students' choice. The second reading materials as the students' choice were taken from library in printed version. Based on this finding, it strengthens the statement that nowadays reading online from internet is preferable.

From $58 \%$ of prose class and $48 \%$ of book report class, there were some internet sources that students visited namely Wattpad, fanfiction.net, americanliterature.com, and some websites of e-book version. More than half of the students (59\%) chose Wattpad as their reading source, other students chose some websites of e-book version (23\%), americanliterature.com (11\%) and fanfiction.net (6\%). Most students from book report and prose classes were familiar with Wattpad. At least, once they read the story from it. Due to the fact that Wattpad became the most visited internet source for their reading materials, investigating the weaknesses and the strengths of that source is vital.

Wattpad itself is a website that can gather all results of writing from different people in different countries and a lot of readers from around the world. Everyone can create his or her own story in this website as long as he or she has an account. Besides, everyone can read many kinds of stories there. Basically, it is an online community for writers and readers to share stories and read the stories. The genres in Wattpad vary from fiction, mystery, nonfiction, adventure, humor, horror, romance, classics, and etc (Wattpad, 2018).

There were some studies that discuss the effect of having Wattpad in reading and writing classes (Aytan, 2017; Bal, 2018; Sari, 2017). Those studies show the positive impact of having Wattpad on the improvement of students' reading comprehension. Based on the data that she has gathered, students showed significant improvement on their reading comprehension achievement because they were excited and curious to know the next story. This happened to some students in book report classes. During the interview session, they expressed their curiosity toward the continuation of the story that they had read. They also said that they wanted to read more. Although Sari found the benefit of using Wattpad that was similar to the condition in book report classes, she wrote some problems of using Wattpad for reading materials in a class. The first related to the limitation of time for each meeting and the second dealt with limited internet connection that could distract students' concentration. These two problems did not occur in book report and prose class, due to the fact that the activity of reading was not done in the class. Before having a class, students had to finish reading stories first.

The second research was conducted by Ball (2018). He compared reading and writing experiences in-school with using Wattpad. He found that in-school reading and writing activities were not quite interesting when it was compared to reading and writing activities using Wattpad. When students had Wattpad, they could express themselves and avoid negative experiences. Students' writing and reading experiences when they used Wattpad were more interesting and engaging. In this study, the negative side of using Wattpad was not stated. Using Wattpad seemed to be an ideal way for gaining students' positive writing and reading experiences.

Moreover, a study that was conducted by Aytan (2017) discussed teacher candidates' writing experiences from Turkey at wattpad.com environment. This study was interesting due to

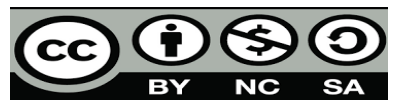

This work is licensed under Creative Commons Attribution-ShareAlike 4.0 Internasional. Copyright @ 2020, Maria Vincentia Eka Mulatsih 
the fact that it did not only provide the advantages of using Wattpad but also the disadvantages. Some of the advantages of using Wattpad were elaborated clearly such as the chances for correcting the spelling error with the help of electronic environment, for having interaction between reader and writer in an attractive visualization, for saving students' time and money, for having direct and different feedbacks from wattpad.com environment.

However, Aytan (2017) also found the disadvantages of using Wattpad. Since, it was in virtual world, some students thought that Wattpad was not reliable. One of the reasons was that people were not so serious. He thought that people were more serious in the real world. Spending much time on the screen of electronic device could cause health problems for students' eyes. Some students also complained for their headache. Beside students could be distracted with some notifications and advertisements on the website, the limitation of wording and character could not be able to accommodate students' creativity too. The important disadvantage of using Wattpad in term of students' psychological aspect dealt with the feedback that the writer got. It could be so severe. In addition to that, Birch (2016) underlined the effects on adolescent writers after gaining online feedback. Aytan's study has shown the disadvantages of having Wattpad from writers' point of view. Considering some previous studies, this article provides some disadvantages of having Wattpad from different point of view.

Specifically, being accepted as the member of Wattpad is quite easy. One of the requirements to be able to have an account is the candidates' age. The writer or reader should be at least 13 years old. This regulation has both positive and negative sides. On one hand, it can improve the literacy of the readers, the creativity of the writers, and the number of various contents from different culture around the world. On the other hand, this regulation provides the chance for immature readers and writers to read or to write inappropriate content.

The implications of that regulation deal with students. Students may begin their reading habit at an early age. They can read frequently some stories which are based on their chosen genre that they like as a result of interesting stories from Wattpad. In this case, the readers find Wattpad stories interesting and are able to evoke curiosity. Young writers can also learn to write and to improve their writing skill through writing stories on Wattpad. Furthermore, readers have the opportunity to know different culture from different writers across countries. At the same time, that regulation enables the candidates of reader or writer to fake their age so that they can be the member of Wattpad. The absence of multilayers process of having new members in Wattpad can be tricky.

Furthermore, there is not any quality control for every writer. It is different from a printed book that is published by a publisher. A printed book or short story needs long time for editing, lay outing, copying, designing, and etc. The editing process in a printed book is usually done meticulously by the editor. In Wattpad, when a writer uploads his or her writing, his writing will automatically appear as one of the works. Editing process which is done by professionals or experts is omitted. This affects to the quality of the works especially the language and the content.

At this point, language was the key issue for most articles in Wattpad. There were three major points in relation to the language of Wattpad stories. The first related to grammatical mistakes. For example, the sentence "if not for circumstances, they would not have been there" (Symplyayisha99) could not be categorized as a well-structured English sentence. Basically, a

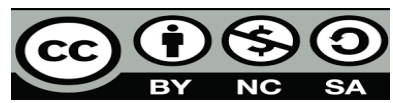

This work is licensed under Creative Commons Attribution-ShareAlike 4.0 Internasional. Copyright @ 2020, Maria Vincentia Eka Mulatsih 
literary work sometimes does not need to have good structure of English. It may have the connection with the style of the writer and other literary devices that the writer wants to create. Unfortunately, the writer's purpose for not having well-structured sentence in this sample story could not be shown clearly. This could be the result of the absence of editing process or the lack of writer's writing experience.

The second weakness related to the absence of a complete sentence. One of the examples was found in a sentence: "The mother of Liam and Anna Williams and Wife to Robert Williams" (Symplyayisha99). As a minimum requirement of a sentence is the presence of subject and predicate. The sample sentence that was taken from Wattpad story only had the subject without any predicate. The third dealt with the inconsistency of the use of tenses. Taken from the same story, there was also an inconsistency of the use of tense for instance "After running several tests on Abigail, the doctor came with the results revealing she was pregnant. She still has a mother to take care ..." (Symplyayisha99). The writer seemed to mix the past tense and present tense when telling the past event.

Not only the language problem, but the content of some stories also was not suitable for students' readability level. The readability level of the first year students of ELESP ranged differently. Mostly, they were in the phase of eleven to thirteen years old (sixth or seventh grade) as intermediate readers. Due to the fact that some stories had specific content that related to adult readers such as having sexual intercourse and love affairs. The gap between the content and the readability could be a problem for the readers. Further studies can be conducted for analyzing the language and the content of Wattpad stories. The story that was used for some examples to show the weakness of the written language on Wattpad was taken randomly as a preliminary study.

Considering some weaknesses from Wattpad, the teachers and lecturers who give freedom to choose the reading materials especially from internet sources can have some additional activities. The activities can be various and they can be done by both lecturers or teachers and students. From the lecturer's or teacher's side, having a reflection after the implementation of reading using Wattpad is recommended. One of the guided question lists can be taken from a book that is written by Benson and Brack (2010) entitled "Online Learning and Assessment in Higher Education" on page 190 until 194.

This article proposed a reflective activity for students. From students' side, the activity may start from finding the mistakes from any website reading material that students choose. This can be done in form of written assignment, pair discussion or group discussion. The goal of this activity is focused on students' understanding e.g. students realize that the structure on some websites may not be perfect. Some guided questions for students to analyze the language are provided in table 1. Guided Questions for Language Quality Measurement below.

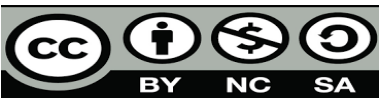

This work is licensed under Creative Commons Attribution-ShareAlike 4.0 Internasional. Copyright @ 2020, Maria Vincentia Eka Mulatsih 


\begin{tabular}{lll}
\hline \multicolumn{3}{c}{ Table 1. Guided Questions for Language Quality Measurement } \\
\hline No & Questions & Answers \\
\hline 1. & $\begin{array}{l}\text { The minimum requirement of a sentence is the presence } \\
\text { of subject and predicate. Did you find any incomplete } \\
\text { sentence on the first page of the story that you have } \\
\text { read? Please write a/some incomplete sentence(s). }\end{array}$ \\
\hline $2 . \quad \begin{array}{l}\text { Did you find an incomplete sentence on the second } \\
\text { page? Please write the sentence. }\end{array}$ \\
\hline $\begin{array}{l}\text { Did you find any grammatical mistake on the first page } \\
\text { of the story? Please write the sentence. }\end{array}$ \\
\hline $\begin{array}{l}\text { Did you find any grammatical mistake on the second } \\
\text { page of the story? Please write the sentence. }\end{array}$ \\
\hline $\begin{array}{l}\text { Based on their findings above, do you think that your } \\
\text { chosen story has good written language? }\end{array}$ \\
\hline $6 . \quad \begin{array}{l}\text { Please provide your reason when you think that your } \\
\text { chosen story has good written language or does not have } \\
\text { good written language. }\end{array}$ \\
\hline
\end{tabular}

When students finish this activity, they may share the result to the whole class. The sharing process of the answers is able to have a conclusion from the whole class.

The second activity is giving the percentage of the language quality of the literary work, in this chase is a story from website. After knowing some grammatical mistakes in a story, students may decide the number of percentage which a story has. This activity can be done individually or in a group. When students do it in a group, lecturer or teacher must ensure that they read the same story. Finding the mistake is similar to those questions in TOEFL structure test without any underlined word. Students may print the first and second pages of the story and underline the mistakes. The benefit of this activity is that students may apply the knowledge of grammatical structure to form a good sentence that they have learned. Besides, this activity can evoke students' awareness on choosing good reading materials.

The activities that are mentioned above are good as long as teacher or lecturer let students enjoy the reading materials first. It is suggested that teachers or lecturers will not give those activities before the reading so that students will not focus on certain goals since students' enjoyment is the main goal. After that, lecturer or teacher can guide students to have their awareness so that they consider again their chosen reading materials. At the end, students realize that beside gaining some benefits from their chosen reading materials, they need to be aware that not all sentences that they read are well-structured.

In line with those activities, Butterfield (2009) shows a real implementation of grounded theory and action research in a school. The self-recognition of reading benefits and goal achievement through investigating the problem, setting the goal, having personal reflection, sharing practice and implementing the reading activities were the key for the staff so that the school had continuous progress. Previous activities which are finding the mistake and levelling the quality

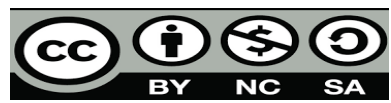

This work is licensed under Creative Commons Attribution-ShareAlike 4.0 Internasional. Copyright ( $\odot$ 2020, Maria Vincentia Eka Mulatsih 
may lead to the self-recognition for each student. So, the students will be aware to choose their reading materials.

The last activity relates to students' reflection. They need to have self-reflection after they find some mistakes and measure the quality of non-printed materials especially from internet sources. It can be done when they find that their reading material is not good enough. After that, lecturer or teacher may persuade students to read the printed version by giving an article that is written by Picton (2014). Some guided questions for students to have their self-reflection are provided in table 2. Guided Questions for Students' Reflection below.

Table 2. Guided Questions for Students' Reflection

\begin{tabular}{lll}
\hline No. & Questions & Answer \\
\hline 1. & $\begin{array}{l}\text { Did I find reading online materials interesting? } \\
\text { Why did I conclude that? }\end{array}$ & $\ldots$ \\
\hline 2. & What did I learn from reading online materials? & $\ldots \ldots$ \\
\hline 3. & $\begin{array}{l}\text { Did I realize that some sentences did not have good } \\
\text { structure? }\end{array}$ & \\
\hline 4. & $\begin{array}{l}\text { Did I learn a lot about the language of online } \\
\text { materials that I read? }\end{array}$ & \\
\hline 5. & $\begin{array}{l}\text { Will I combine my online reading materials with } \\
\text { printed materials? }\end{array}$ & \\
\hline
\end{tabular}

Moreover, this activity is the solution for accommodating both interests (online reading and printed version). It can also arouse students' competence. It is the same like Picton's (2014) term that is "a mixed reading diet". He says that "a mixed reading diet" is to read both printed and non-printed such as from tablet, computer, smart phone. He cites from PISA (2009) that "although students who read fiction are more likely to achieve high scores, it is students who read a wide variety of material who perform particularly well in reading". In short, students are encouraged to read both printed and not printed reading materials. Those three strategies that have been mentioned above can be applied so that students can avoid the weaknesses of reading from internet today.

\section{CONCLUSION}

Reading non printed materials becomes popular in this $21^{\text {st }}$ century and this kind of reading cannot be avoided any longer. It also happened with students who took Book Report and Prose classes in 2018. It was shown that the number of students who enjoyed reading non printed materials increased significantly. In prose class, more than half number of students read non printed reading materials and in book report class, almost half number of students chose stories from online sources.

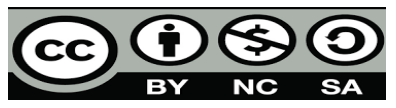

This work is licensed under Creative Commons Attribution-ShareAlike 4.0 Internasional. 
Although students could achieve the main goal of reading that was the enjoyment, this article found the weaknesses of the most visited website that was used for their reading materials. This study discussed one of the most visited website for students' reading materials that was Wattpad. On one hand, previous studies showed that this website could give many advantages for both readers and writers for having a chance to express their interest. On the other hand, Wattpad stories had some weaknesses that were related to the absence of editing and the quality of the language. Those two weaknesses should be the main concerns after reading process completed.

Due to those reasons, the writer proposed some activities to anticipate the negative effects of reading Wattpad stories for students who took for granted for copying the language. They are in form of additional activities after students finish their reading for enjoyment. The first is finding the grammatical mistakes in a story. The second is levelling the quality of language of the story that student reads. The third is doing self-reflection for each student to know whether the story can give benefits for the student or the contrary. By doing these activities, writer hopes that students can experience "mix their reading diet" as what Picton argues. Other benefit of having those activities is that it can increase students' ability to analyse and to think critically. In short, the importance of students' comprehension that they might enjoy most literary devices such as characterization, style, point of view, theme in Wattpad stories could not be taken apart from students' understanding that the language in Wattpad stories still needed many revisions.

This article also proposes some themes for future researchers. Firstly, future researchers may investigate the reading benefit of combining two media of reading from internet and from printed material. Secondly, they also can analyse more about the effects of applying the proposed activities namely, finding the mistakes, giving the percentage for the language quality, and doing self-reflection for students whether it can improve their critical thinking or their language skill. This can also be connected with students' awareness to choose good materials for their reading. 


\section{REFERENCES}

[1] Allington, D., \& Pihlaja, S. (2016). Reading in the age of the internet. Language and Literature, 25(3), 201-202.

[2] Asraf, R. M., \& Ahmad, I. S. (2003). Promoting English language development and the reading habit among students in rural schools through the Guided Extensive Reading program. Reading in a Foreign Language, 15(2), 83.

[3] Aytan, T. (2017). Evaluation of Electronic Writing Experiences of Turkish Teacher Candidates at WATTPAD Environment. Higher Education Studies, 7(4), 1-8.

[4] Bal, M. (2018). Reading and Writing Experiences of Middle School Students in the Digital Age: Wattpad Sample. International Journal of Education and Literacy Studies, 6(2), 89-100.

[5] Benson, R., \& Brack, C. (2010). Online learning and assessment in higher education: A planning guide. Elsevier.

[6] Berardo, S. A. (2006). The use of authentic materials in the teaching of reading. The reading matrix, $6(2)$.

[7] Birch, H. J. (2016). Feedback in online writing forums: Effects on adolescent writers. Teaching/Writing: The Journal of Writing Teacher Education, 5(1), 5.

[8] Bowen, G. A. (2009). Document analysis as a qualitative research method. Qualitative research journal, 9(2), 27-40.

[9] Butterfield, J. (2009). Using grounded theory and action research to raise attainment in, and enjoyment of, reading. Educational Psychology in Practice, 25(4), 315-326.

[10] Clark, C. (2010). Linking School Libraries and Literacy: Young People's Reading Habits and Attitudes to Their School Library, and an Exploration of the Relationship between School Library Use and School Attainment. National Literacy Trust.

[11] Clark, C., \& Rumbold, K. (2006). Reading for Pleasure: A Research Overview. National Literacy Trust.

[12] Clark, C., \& De Zoysa, S. (2011). Mapping the Interrelationships of Reading Enjoyment, Attitudes, Behaviour and Attainment: An Exploratory Investigation. National Literacy Trust.

[13] Clark, C., \& Douglas, J. (2011). Young People's Reading and Writing: An In-Depth Study Focusing on Enjoyment, Behaviour, Attitudes and Attainment. National Literacy Trust.

[14] Coiro, J. (2003). Exploring literacy on the internet: Reading comprehension on the internet: Expanding our understanding of reading comprehension to encompass new literacies. The reading teacher, 56(5), 458-464.

This work is licensed under Creative Commons Attribution-ShareAlike 4.0 Internasional. 
[15] Dewi, N. (2018). Studying English literature in Indonesia: Challenges and opportunities. Lire Journal (Journal of Linguistics and Literature), 2(2), 50-56.

[16] Flood, A. (2014). Readers absorb less on Kindles than on paper, study finds. The Guardian, 19.

[17] Ghazali, S. N. (2016). Learner background and their attitudes towards studying literature. Malaysian Journal of ELT Research, 4(1), 17.

[18] Huh, M. H., \& Ha, H. S. (2017). Reading Children's Literature in an EFL Writing Class: Tales of Two College Students. English Teaching, 72(3).

[19] Leu, D. J., Karchmer, R. A., \& Leu, D. D. (1999). Exploring Literacy on the Internet: The Miss Rumphius Effect: Envisionments for Literacy and Learning That Transform the Internet. The Reading Teacher, 52(6), 636-642.

[20] Lien, H. Y. (2017). EFL College Learners' Perceptions of Self-Selected Materials for Extensive Reading. The English Teacher, 11.

[21] Mangen, A., Walgermo, B. R., \& Brønnick, K. (2013). Reading linear texts on paper versus computer screen: Effects on reading comprehension. International journal of educational research, 58, 61-68.

[22] Mulatsih, M. I. (2018). Learning poetry as a strategy to develop teaching skill among students. International journal of Indonesian education and teaching (IJIET), 2(2), 120128.

[23] Ndandara, A. (2017). Justification of The Asian Literary Canon. Lire Journal (Journal of Linguistics And Literature), 1(1), 1-10.

[24] Nordin, R., \& Eng, L. S. (2017). Text-Selection for Teaching Reading to ESL Tertiary Students: A Study on Genre and Content Preferences. International Journal of Instruction, 10(1), 71-84.

[25] Nuttal, C.(1982). Teaching reading skills in a foreign language. Oxford: Heinemann English Language Teaching.

[26] Park, H. R., \& Kim, D. (2011). Reading-strategy use by English as a second language learners in online reading tasks. Computers \& Education, 57(3), 2156-2166.

[27] Picton, I. (2014). The Impact of eBooks on the Reading Motivation and Reading Skills of Children and Young People: A Rapid Literature Review. National Literacy Trust.

[28] Prowse, P. (2002). Top ten principles for teaching extensive reading: A response. Reading in a foreign language, 14(2), 142-145.

[29] Rowberry, S. P. (2016). Commonplacing the public domain: Reading the classics socially on the Kindle. Language and Literature, 25(3), 211-225.

This work is licensed under Creative Commons Attribution-ShareAlike 4.0 Internasional. 
[30] Salaverría, R. (2005). An immature medium: Strengths and weaknesses of online newspapers on September 11. Gazette (Leiden, Netherlands), 67(1), 69-86.

[31] Sari, D. P. (2017). The effects of short story through wattpad on reading comprehension achievement of non-english major students of Bina Darma University. HOLISTICS, $8(16)$.

[32] Son, J. B., Robb, T., \& Charismiadji, I. (2011). Computer literacy and competency: A survey of Indonesian teachers of English as a foreign language. Computer-Assisted Language Learning Electronic Journal (CALL-EJ), 12(1), 26-42.

[33] Strout, K. L. (2010). Average, Below Average, And Above Average First Grade Students' Beliefs about Using E-Books to Activate Interest and Motivation in Reading (Doctoral dissertation, Bowling Green State University).

[34] Wattpad. (2018). https://www.wattpad.com/?locale=tr_TR adresinden erişildi. Retrieved on $5^{\text {th }}$ September 2019.

[35] Wästlund, E., Reinikka, H., Norlander, T., \& Archer, T. (2005). Effects of VDT and paper presentation on consumption and production of information: Psychological and physiological factors. Computers in human behavior, 21(2), 377-394.

[36] Wulandari, H. (2019). English teachers' cultural background and their teaching belief. Lire Journal (Journal of Linguistics and Literature), 3(1), 43-52.

[37] Yamashita, J. (2008). Extensive reading and development of different aspects of L2 proficiency. System, 36(4), 661-672.

Online source:

https://www.wattpad.com/477379941-the-secret-babies-completed-prologue (Symplyayisha99) 